\title{
BioLink
}

Jurnal Biologi Lingkungan, Industri, Kesehatan

\section{THE EFFECT OF COCOPEAT AND RICE HUSK PLANTING MEDIA HYDROPONICALLY ON THE GROWTH OF PALM OIL IN PRE NURSERY}

\author{
Aulia Juanda Djaingsastro*, Hardiansyah Sinaga, \& Ranto Mangasi Sitorus \\ Plantation Cultivation Study Program, STIPER Agrobisnis Perkebunan, Indonesia
}

Submited : 25-08-2020; Reviewed :06-10-2020; Accepted : 23-12-2020

*Corresponding author: E-mail : aulia juanda@stipap.ac.id

\begin{abstract}
Palm oil can produce high productivity which must be supported from several aspects, one of them is a good and correct nursery. Palm oil nursery isusually carried out conventionally, namely planting using soil media. Hydroponic research using cocopeat and rice husks planting media on the growth of palm oil seeds in pre nursery has never been carried out. The objective of this study was to determine the growth of palm oil seedlings using the hydroponic method. This research was conducted in the STIPAP Medan greenhouse. This research was conducted from April to July 2018. This research was a non-factorial RAK, which consisted of four treatments, namely MO (top soil), M1 (Cocopeat), M2 (rice husks), M3 (combination). Height, stem, number of leaves, dry and wet weight of roots and plants, root length were observed. Then data analysis with ANOVA with the continued test of 5\% Duncan was performed. The results of the effect of cocopeat and rice husk media was there was no a significant effect on the treatment parameters of seed height, number of leaves, dry and wet weight of roots and plants, and root length.
\end{abstract}

Keywords: Palm oil seedlings; Plant media; Hydroponics

How to Cite: Djaingsastro, A.J., Sinaga, H., \& Sitorus, R.M. (2021). The Effect of Cocopeat and Rice Husk Planting Media Hydroponically on The Growth of Palm Oil in Pre Nursery, BioLink: Jurnal Biologi Lingkungan, Industri dan Kesehatan, Vol.7 (2): Hal. 195-203 


\section{INTRODUCTION}

Palm oil (Elaeis guineensis) is one of the plantation crops that contributes to the largest foreign exchange for Indonesia. For vegetable oil producers, palm oil is superior to its competitors, namely soybean, sunflower, Conola and so on.

In Indonesia, palm oil plantation area in 2017 was 12,307,677 Ha with CPO production of $35,359,384$ tonnes, increased from production in 2016 (Indonesian Plantation Statistics, 2018).

According to Usman (2014) Nursery is an important thing in cultivating palm oil plants. The initial growth of seedlings is a critical period that determines the success of plants in achieving good growth in the nursery. One of the efforts that can be done during the initial seeding of the palm oil is by applying fertilizer.

The problem of palm oil found in Indonesia is quite complex, which can lead to low productivity. Palm oil nursery is the first step that can support the success of the plantation (Sartini et al., 2018). The other determining factors in seed processing are influenced by the planting medium used. Laisan soil or so-called top soil is generally used which has higher fertility, according to the Palm oil Research Center, the thickness of the top soil is $10-30 \mathrm{~cm}$ which is commonly used in palm oil nursery. The planting media greatly affects the growth of the seeds to be planted, so it is necessary to choose the right planting medium. Loose, fertile, light, cheap and easy to obtain are the characteristics of a good planting medium for nursery.

Rice husks and cocopeat are cheap agricultural waste products and easy to obtain (Novita et al.,2012). The cocopeat is composed of lignesellulose compounds (complex lignin, cellulose, and hemicelluloses). Hermicellulose is hydrofibile (absorbs water easily) which results in an irregular structure and in dry hygroscopic cellulose (absorbs water well), hard, and brittle. The nature of cellulose is that it is not dissolved in water and is very easy to absorb water (Nisa \& Widya, 2014; Chairunnisa et al., 2019). Hydroponics is a method of planting without using soil, which is different from conventional methods that are often using soil.

Some organic waste has the potential for hydroponic liquid fertilizer, Based on Andriyeni et al., (2017) the macro nutrient content of catfish culture wastewater has a pH of 7-8, C-organic 16.28 - 24.64\%, and a $\mathrm{C} / \mathrm{N}$ ratio of $1.71-12 \%$.

Land availability is one of the limiting factors for the growth and production of palm oil. Its specific purpose is to test and to obtain information on the effect of various media for planting palm oil seedlings as well as the influence of the planting media on palm oil seeds with a hydroponic system. The target of this study 
is expected to know the comparison of planting media in nursery by means of hydroponics. Contribution of this study is expected to increase knowledge for farmers and palm oil plantations about palm oil nursery by means of hydroponics.

\section{MATERIALS AND METHODS}

This study was conducted in the STIPAP Medan greenhouse. The study period was from April-July 2018. Nonfactorial randomized block design (RBD) with treatment of M0 (top soil media), M1 (cocopeat), M2 (rice husk), M3 (cocopeat mixed with rice husks). Each sample/population was 3 times. The total of seedlings was 48 seeds. Sidik Analysis Variety of data was processed. The materials used were palm oil sprouts from PPKS DxP Langkat variety, polybags, cocopeat, rice husks, water, ABMix nutrition. The tools used were plastics, water pumps, hoses, TDS meters, $\mathrm{pH}$ meters, analytical scales, measuring cups, stationery.

\section{Research Stages:}

The plant material used the sprouts from Medan PPKS (DxP PPKS Langkat variety).

Polybag filling used ultisol soil, which dry it first. Then it was sieved to remove the remaining wood and roots, then fulfilled it in a poly bag so that no cavities occurred and the level was left approximately $2 \mathrm{~cm}$. Likewise with cocopeat and rice husks, the poly bag was fulfilled so that there was no cavity then flushed it until really solid. Watering was done a day before planting sprouts, soil, cocopeat and rice husks in polybags until they are completely wet. Planting 1 sprout in each polybag in $2 \mathrm{~cm}$ deep from the planting surface. Adding nutrients after checking the concentration every day and for conventional media using urea fertilizer with a reference dose that has been determined by PPKS.

\section{Observation and Indicator}

Height of plant was measured from the base of the stem (palm bole) to the tip of the highest leaf using a tape measure. Measurements were done at the age of 4 weeks to 12 weeks of seedlings in once a week. Counting the total number of leaves that had been opened completely. Measurements were done at the age of 4 weeks to 12 weeks of seedlings in once a week.

The root wet weight data were collected by separating the roots from the top of the plant on the basis of the midrib (bole) by using a sharp knife. Observation was done at the end of the observation. Root dry weight data were collected from all parts of the roots that had been separated from the plant crown and then put them in the oven until a constant 
weight was obtained. Observation was done at the end of the observation.

Weighing all parts of the plant was done at the end of the study so that the wet weight was obtained. Putting all parts of the plant at the end of the observation in the oven until the constant weight was obtained. The root length observation was carried out at the end of the observation by measuring the entire root from the weevil (bole) to the root tip.

\section{RESULTS AND DISCUSSION}

Based on the research data, it was found that the parameters of the height of the seedlings in the treatment started 28 days ( 4 weeks) after planting to 84 days (12 weeks) it was found that the largest average height observation was in the M0 treatment, namely $23.25 \mathrm{~cm}$. While the smallest average height was found in M2 treatment, namely $22.29 \mathrm{~cm}$ (Table 1 . Plant Height). Rice husks and cocopeat were cheap agricultural waste products and easy to obtain (Novita et al., 2012).

Based on the variance, it showed that the treatment of the planting medium had no significant effect: seedling height at the 4 th to 12 th observation weeks after planting. The height growth of palm oil seedlings at M0, namely the soil medium, showed the highest number, namely 31.35 $\mathrm{cm}$. On M1, the highest number was 31.30 $\mathrm{cm}$. M2 shows the highest figure at 30.23 $\mathrm{cm}$. The M3 shows the highest number at $31.58 \mathrm{~cm}$.

Table 1. Seed Height (cm)

\begin{tabular}{ccccc}
\hline Seed Age & M0 & M1 & M2 & M3 \\
\hline 4 MST & 14.92 & 13.98 & 13.44 & 13.62 \\
5 MST & 17.00 & 15.93 & 15.45 & 15.66 \\
6 MST & 19.52 & 18.34 & 17.82 & 18.93 \\
7 MST & 21.39 & 20.37 & 20.58 & 20.89 \\
8 MST & 22.66 & 22.54 & 22.04 & 22.40 \\
9 MST & 25.79 & 25.25 & 25.58 & 25.73 \\
10 MST & 27.57 & 27.81 & 27.38 & 28.31 \\
11 MST & 29.09 & 28.75 & 28.08 & 29.14 \\
12 MST & 31.35 & 31.30 & 30.23 & 31.58 \\
\hline Total & 209.28 & 204.26 & 200.58 & 206.26 \\
Average & 23.25 & 22.70 & 22.29 & 22.92 \\
\hline
\end{tabular}

The parameters of measured plant height indicated that the cocopeat media in palm oil seedlings was able to store water for the needs of palm oil plants so that it could maintain the humidity of the cocopeat planting media. Since in the cocopeat there are chemical compounds, namely legnin, cellulose, and hemicellulose which have long and strong fibers so they can absorb water. It is in accordance with 
the opinion of (Dixit \& Preeti, 2012; to produce a greater number of leaves Vidianto et al.,2013) lignocellulosic fibers (strands) than the soil medium. Utami are hydrophilic and able to absorb (2015) stated that the increasing in plant moisture so that the needs of water are height can support the increasing in the fulfilled and have an effect on the plants. number of leaves as the plant ages.

Result of Variance prints is in table 2.

It is suspected that the cocopeat Number of leaves showed that the media could help the planting media to influence of the planting medium had an hold the water content which was much effect but not significant on the parameter needed by palm oil. The need for of the increasing number of leaves of palm oil seedlings. The highest total leaves adequate water for plants was very growth of all treatments was M1, namely important. If groundwater was lacking for 4.17. While the lowest was M2 with 3.92 plants, the photosynthesis process was not strands. Although it did not show a hampered, which would have an impact on significant difference at the $5 \%$ level, the vegetative growth and productivity. Here is treatment of the growing medium tended the number of leaves counted (table 2).

Table 2 Number of Leaves (Strands)

\begin{tabular}{ccccc}
\hline Age of seeds & M0 & M1 & M2 & M3 \\
\hline 4 MST & 0.67 & 0.83 & 0.92 & 1.00 \\
5 MST & 1.33 & 1.50 & 1.50 & 1.50 \\
6 MST & 1.67 & 1.83 & 1.67 & 1.83 \\
7 MST & 2.00 & 2.08 & 2.08 & 2.08 \\
8 MST & 2.33 & 2.83 & 2.75 & 2.92 \\
9 MST & 2.92 & 3.00 & 3.00 & 3.00 \\
10 MST & 3.08 & 3.17 & 3.00 & 3.08 \\
11 MST & 3.67 & 4.00 & 3.58 & 3.50 \\
12 MST & 4.00 & 4.17 & 3.92 & 4.00 \\
\hline Total & 21.67 & 23.42 & 22.42 & 22.92 \\
Average & 2.41 & 2.60 & 2.49 & 2.55 \\
\hline
\end{tabular}

Results in Table 3. Bobot Basah Akar root wet weight is $2.49 \mathrm{~g}$, and the lowest Dapat. can in each of the planting media root wet weight measurement is M2 treatments at 12 MST (weeks after around $2.15 \mathrm{~g}$. planting), it can be seen that the highest 
Djaingsastro, A.J., Sinaga, H., \& Sitorus, R.M. The Effect of Cocopeat and Rice Husk Planting Media Hydroponically on The Growth of Palm Oil in Pre Nursery

Table 3.Wet Root Weight (gr)

\begin{tabular}{cc}
\hline Treatment level & Root wet weight (gr) \\
\hline M0 & 2.49 \\
M1 & 2.40 \\
M2 & 2.15 \\
M3 & 2.24 \\
\hline
\end{tabular}

Wet weight of roots after dismantling scales in grams. Genetic traits, soil without any drying process first. Then the conditions, or the growing medium of the weighing was carried out using analytical plant would show the system.

Table 4. Root Dry Weight (gr)

\begin{tabular}{cc}
\hline Treatment level & Root dry weight (gr) \\
\hline M0 & 0.65 \\
M1 & 0.46 \\
M2 & 0.51 \\
M3 & 0.47 \\
\hline
\end{tabular}

It can be seen that the root dry weight Stunted root elongation was then in each planting medium treatment at 12 followed by secondary growth, namely root MST showed that the highest root dry expansion caused by the activity of the weight was $0.65 \mathrm{gr}$. The dry weight of the lateral meristem, namely the formation of roots, after unloading, weigh the wet the cambium. The widening of the roots weight first, then do the oven. Weighing is caused the root diameter increase which in carried out using analytical scales in grams. turn affects the dry weight of the roots.

Table 5. Seed Wet Weight (gr)

\begin{tabular}{cc}
\hline Treatment level & Plant wet weight \\
\hline M0 & 10.00 \\
M1 & 9.00 \\
M2 & 9.00 \\
M3 & 9.00 \\
\hline
\end{tabular}

It showed that the wet weight of palm oil seedlings at 12 WAP, namely at the time of unloading the plants, the M0 planting medium showed the highest number, which was $10.00 \mathrm{gr}$ and in the treatment of cocopeat, roasted rice husk and cocopeat, the lowest was $9.00 \mathrm{gr}$. The role of the element $\mathrm{N}$ for plants was to stimulate the growth of plant height, especially on stems and leaves, thereby increasing the wet weight of the plant.

Research by (Frasetya et al., 2018) showed that the EC treatment of $1.7 \mathrm{mS} / \mathrm{cm}$ and $2.4 \mathrm{mS} / \mathrm{cm}$ produced the highest plant 
fresh weight of $79.32 \mathrm{mS} / \mathrm{cm}$. It can be seen volume, which will increase the wet weight from the increasing in plant height and root of palm oil plants.

Table 6. Seed Dry Weight (gr)

\begin{tabular}{cc}
\hline Treatment level & Seed dry weight \\
\hline M0 & 1.80 \\
M1 & 1.80 \\
M2 & 2.90 \\
M3 & 2.30
\end{tabular}

According to (Rahmadhani et al., the highest number was 2.90 gr and in the 2020, root biomass is strongly influenced treatment of M0 planting media and M1 by root volume and number of roots. The planting media, the lowest was $1.80 \mathrm{gr}$. The greater the number of roots is, the greater dry weight of the seeds formed reflects the the root volume and biomass is. It shows amount of photosynthesis as a result of that the dry weight of palm oil seedlings at photosynthesis. Since dry weight is very 12 WAP, which is at the time of unloading dependent on the rate of photosynthesis. the plants, the M2 planting medium shows

Table 7. Root Length (cm)

\begin{tabular}{cc}
\hline Treatment Level & Root Length \\
\hline M0 & 35.80 \\
M1 & 27.50 \\
M2 & 47.70 \\
M3 & 38.60 \\
\hline
\end{tabular}

Whereas the root length of palm oil seedlings at 12 weeks after planting, namely at the time of unloading the plants, the M2 planting medium showed the highest number, $47.70 \mathrm{~cm}$ and the lowest M1 planting medium, $27.50 \mathrm{~cm}$. The root length parameter showed that the growing media on rice husks at 12 WAP observations the highest number is 47.70 $\mathrm{cm}$. Since rice husks have a lot of hollow or porous forms (Crumb), good drainage and water. This is based on Taufiqullah's opinion (2017) that plant roots will be easy to get through the form of porous soil, so that the roots will develop properly. The crumbly soil structure will make it easier for the roots to pass through, so that the plant growth was higher and had longer roots.

According to (Delaide et al., 2016) fish fece waste contains microorganisms and a high content of dissolved organic matter which plays an important role in supporting the crown and roots, especially 
root volume. So it is possible that cocopeat and rice husk have microorganisms that are useful for affecting the length of the roots of palm oil seedlings.

Farida et al., (2017) stated that for hydroponic tds (ppm) 900 - 1,400, solution $\mathrm{pH}$ of 6.5 - 6.9. It is in accordance with the research we conducted where the $\mathrm{pH}$ was not more than 7 and not too low than 6 and the maximum results.

According to Syarif (2013) the element of Phosphorus (P) has functions to transport metabolic energy in plants, to stimulate flowering and fertilization, to stimulate root growth, to stimulate ordered seeds, to estimulates plant cell division and enlarges cell tissue. The plants that lack $\mathrm{P}$ elements has some characteristics : reduced fruit/seeds, stunted, purplish or reddish leaves (less healthy).

According to (Siregar et al., 2015) the elements in the solution could be absorbed by plants, their availability was largely determined by $\mathrm{pH}$. Some elements had a certain $\mathrm{pH}$ value range, $\mathrm{N}$ was at at pH 5.5 - 7.5 while $\mathrm{K}$ at $\mathrm{pH} 5.5$ - 10 while micro elements were relatively available at low pH. The availability of essential elements in relation to $\mathrm{pH}$ means that to carry out field experiments it is recommended that they be carried out in areas with a pH of approximately 7 .

\section{CONCLUSION}

From the research results, it can be concluded that the use of cocopeat planting media had no significant effect on all observations, but the best number of leaves was on cocopeat media. The use of rice husk media did not significantly affect the overall parameters observed, but the dry weight and root length were better for rice husk media. In all observations, cocopeat media mixed with rice husks had no significant effect. The cocopeat media mixed with rice husk was the best for plant height parameters.

\section{REFERENCES}

Andreeilee,B.F.,Santoso,M., dan Nugroho, A. (2014). Pengaruh jenis kompos kotoran ternak dan waktu penyiangan terhadap produksi tanaman pakcoy (Brassica rapasub.chienensis) organik. Produksi Tanaman,2(3):190-197.

Andriyeni, A., Firman, F., Nurseha, N., dan Zulkhasyni, Z. (2017). Studi potensi hara makro air limbah budidaya lele sebagai bahan baku pupuk organik Agroqua, 15 (1):71-75.

Chairunnisa, C., Riyanto, R., \& Karim, A. (2019). Isolasi dan Uji Bakteri Lipolitik dalam Mendegradasi Minyak Pada Limbah Cair Kelapa Sawit di Kebun Marihat, Pematang Siantar. Jurnal Ilmiah Biologi UMA (JIBIOMA), 1(2), 44-52.

Delaide, B., Goddek, S., Gott, J., Soyeurt, H. and Jijakli, M.H. (2016). Lettuce (Lactuca sativa L. var. Sucrine) growth performance in complemented aquaponic solution outperforms hydroponics.Water,8(10):467.

Farida, N.F., Abdullah,S.H. dan Priyati, A. (2017). Analisis kualitas air ada sistem pengairan akuaponik. Ilmiah Rekayasa Pertanian dan Biosistem, 5 (2): 385-394. 
Frasetya, B., Taofik,A. dan Firdaus, R.K. (2018). Evaluasi variasi nilai electrical conductivity terhadap pertumbuhan tanaman selada (Lactuca sativa L.) pada sistem NFT. Agro,5(2):95-102

Novita, D., I. Juliyarsi dan G. Fuadi. (2012) Kadar Protein, kadar Lemak dan Organileptik Telur Asin Asap Berbahan Bakar Sabut Kelapa. Fakultas Perternakan Universitas Andalas. Padang

Pamujiningtyas. B. K. dan A. D. Susila. (2015). "Pengaruh Aplikasi Naungan dan Pupuk Daun terhadap Pertumbuhan dan Produksi Selada (Lactuca sativa Var. Minetto) dalam Teknologi Hidroponik Sistem Terapung (THST)". Skripsi. Departemen Budidaya Pertanian. IPB, Bogor.

Rahmadhani, Laela Endah, Laily Ilman Widuri, Parawita Dewanti. (2020). Kualitas Mutu Sayur Kasepak (Kangkung, Selada, dan Pakchoy. Jurnal Agroteknologi Vol. 14 No. 01.

Sartini, S., Fitriani, R., \& Lubis, R. (2018). Pengaruh Kadar Asam Sulfat Pada Hidrolisis Tandan Kosong Kelapa Sawit (TKS) Dan Waktu Fermentasi Terhadap Kadar Bioetanol Yang Dihasilkan. BIOLINK : Jurnal Biologi Lingkungan Industri Kesehatan, 4(2), 152159

Siregar, J., S. Triyono, dan D. Suhandy. (2015). Pengujian beberapa nutrisi hidroponik pada selada (Lactuca sativa L.) dengan teknologi hidroponik sistem terapung (THST) termodifikasi. Teknik Pertanian,4 (2): 65-72. Statistik Perkebunan Indonesia. (2018). Kelapa Sawit 2017-2019. Direktorat Jendral Perkebunan.

Sunarko, (2010). Budidaya dan Penggolaan Kebun Kelapa Sawit dengan Sistim Kemitraan. Agromedia Pustaka. Jakarta.

Syarif, I. (2013). Peranan Hara Makro. http://syarifirwan.blogspot.co m/2013/o6/fungsi-unsur-haramakro-n-pk.html. Diakses tanggal 20 April 2019

Usman, E., Meriyanto, dan Haris. (2014). Respon Pertumbuhan Bibit Kelapa Sawit (Elaeis guineensis Jacq) Diprenursery Akibat Pemberian Pupuk Melalui Daun. Jurnal Agroteknologi. 6 (2):41-47.

Utami, S. (2005). "Pengaruh Sistem Olah Tanah Terhadap Pertumbuhan dan Hasil Jagung Manis (Zea mays SaccharataStrurt)". Skripsi. Fakultas Pertanian Universitas Muhammadiyah Yogyakarta, Yogyakarta.

Vidianto, D. Z., S. Fatimah, dan C. Wasonowati. (2013). Penerapan panjang talang dan jarak tanam dengan sistem hidroponik NFT (Nutrient Film Technique) pada tanaman kailan (Brassica leraceae var. alboglabra). Agrovigor, 6 (2): 128-135. 